\title{
The relationship between return on investment and the market share of certain listed companies in selected market sectors: 1975 - 1985
}

\author{
P.W.C. de Wit \\ Department of Business Economics, University of Pretoria, Pretoria, 0001 Republic of South Africa \\ N.J.R. Steyn* \\ P.O. Box 17243, Groenkloof, Pretoria, 0027 Republic of South Africa
}

Accepted 7 April 1988

\begin{abstract}
During a theoretical study of company objectives it was found that it is generally assumed that a positive relationship exists between return on investment and the market share of a company. Examination of the formula for calculating return on investment shows, however, that this may not necessarily be the case. As existing studies regarding this relationship could not give any clarity, the need arose for a South African based study. An empirical study was accordingly executed on listed retail stores and companies involved in the manufacturing and distribution of furniture. The period involved was 1975-1985. No meaningful relationship between return on investment and market share could be found. Various recommendations that may lead to more conclusive results during future research were made. The need for accurate findings exists to establish whether the marketing objective is in line with the company objective.

Tydens 'n teoretiese studie van ondernemingsdoelwitte is gevind dat daar algemeen aangeneem word dat daar 'n positiewe verband tussen rentabiliteit en die markaandeel van 'n onderneming is. Indien die formule vir die berckening van rentabiliteit beskou word, kan afgelei word dat dit nie noodwendig altyd waar is nie. Aangesien bestaande ondersoeke na die moontlike verband tussen rentabiliteit en die markaandeel geen duidelikheid kon bied nie, het die behoefte ontstaan na 'n studie gebaseer op Suid-Afrikaanse ondernemings. 'n Empiriese studie is gevolglik gedoen oor genoteerde kleinhandelaars en genoteerde ondernemings betrokke by die vervaardiging en verspreiding van meubels. Die tydperk betrokke was 1975-1985. Geen betekenisvolle verwantskap tussen rentabiliteit en die markaandeel kon gevind word nie. Verskeie aanbevelings wat tot meer akkurate gevolgtrekkings kan lei, word gemaak. Die behoefte aan akkurate gevolgtrekkings bestaan ten einde te kan bepaal of die bemarkingsdoelwit op die ondernemingsdoelwit afgestem is.
\end{abstract}

*To whom correspondence should be addressed

Every company is founded with a specific objective in mind. As a matter of fact, the defining of a company's objective is the first step in establishing the company. Looking at the literature of marketing, one often finds that a positive relationship is assumed between return on investment and the market share. The formula for calculating the return on investment shows, however, that a large market share can be harmful under certain circumstances, i.e. where a loss per unit sold is made. It is also possible that a company can have a satisfactory return on investment with a low market share, i.e. where a high profit margin is obtained per unit.

\section{Theoretical study}

\section{Background}

A theoretical study was firstly conducted in order to establish a background against which the empirical study could be judged. This theoretical study was commenced with the various definitions of company objectives. These various definitions lead to the conclusion that the subject of company objectives is a complicated one about which no unanimity exists. It appeared, however, that profit of some or other kind was subjacent, whether the company was siriving for maximum profit, satisfactory profit or just enough profit to fulfil a social need.

\section{Return on investment}

Following the study about objectives in general, more specific objectives were looked at, namely the maximizing of return on investment and the maximizing of market share. A study was made of the various elements of which the concept of return on investment exists, in order to identify as many as possible influencing factors. Return on investment is calculated by means of the following formula (Rädel \& Reynders, 1980: 432).

$\frac{\text { Profit }}{\text { Sales }} \times \frac{\text { Sales }}{\text { Capital }}$

Looking at the above formula it can be concluded that the following measures can be taken to increase the return on investment:

(i) increase sales;

(ii) decrease capital invested; and

(iii) decrease the total cost while all other factors remain constant (Garrison, 1985: 456).

Various pros and cons exist for the maximizing of return on investment as company objective (Garrison, 1985: 455-456; Koontz, O'Donnell \& Weihrich, 1984: 623-624; Monroe, 1979: 214-217). With this in mind the conclusion was made that return on investment as such is 
still a handy measure of a company's effectiveness, because the company's financial state of affairs can be derived from it (Faul, Pistorius \& Van Vuuren, 1981: 544-548). Note has been taken, however, of a movement away from the maximizing of return on investment as the sole company objective. Possible objectives like the maximizing of wealth or the maximizing of the market share was also found in the literature.

\section{Market share}

Although the maximizing of market share has taken such a prominent position in the hierarchy of objectives, it has often been mistaken for being the company's main objective. It actually is a sales objective. A general assumption was also made that a positive relationship existed between return on investment and the market share. Baumol (1959: 45) found that in several companies the formal objective often differed from those management were striving for. Especially oligopolistic companies' managements were striving for increased turnover, while the owners were aiming for the maximizing of the rate of return. Hise \& Strawser (1972: 8) also found widespread evidence of the assumption that market share should be maximized at all cost. It is generally viewed as a 'fair' measurement of management's efficiency (Hansen, 1958: 778).

With this uncertainty regarding the market share's importance in mind, various studies testing the relationship between return on investment and the market share were looked at.

\section{Studies testing the relationship between return on investment and the market share}

Most studies testing the relationship between return on investment and the market share were based on the data compiled by the Strategic Institute of Planning at Cambridge's 'PIMS' (Profit Impact of Market Strategies) data bank.

Firstly two studies were looked at which found a positive relationship between return on investment and the market share (Schoeffler, Buzzell \& Heany, 1974: 137-145 and Buzzell, Gale \& Sultan, 1975: 97-106). Although a positive relationship was found, neither of the two studies succeeded convincingly to explain the phenomenon.

Two studies, proving that no meaningful relationship existed between return on investment and the market share, were selected. The first one (Jacobson \& Aaker, 1985: 11-22) also used the PIMS data bank. They suspected the relationship found in previous studies to be spurious rather than causal. Subsequently they postulated that the relationship found in previous studies was due to possible third factors. This implied that both return on investment and the market share responded in the same way to a third factor, i.e. management quality. By building in a lag-factor into return on investment they found meaningful evidence that their theory might be true.

Hise \& Strawser (1972: 8-20) also found that the possible positive relationship between return on investment and market share should not be over estimated. Their study was based on data obtained from 97 companies from Fortune's list of the 600 largest companies in the United States of America.

Wagner (1984: 121-135) investigated the long-term influence of a purposive change in market share on return on investment. The main conclusion of this study was that the reaction of return on investment on a change in market share could not be predicted accurately.

\section{The importance of a relationship between return on investment and market share}

If a positive relationship between return on investment and market share could be proved, strategies regarding the building, holding or harvesting of market share could be fruitfully incorporated in the overall company strategy (Buzzell, Gale \& Sultan, 1975: 102; Catry \& Chevalier, 1974: 31; Bloom \& Kotler, 1975: 67-68; Buzzell \& Wiersema, 1981: 136-141). This relationship is also of importance in the following cases:

(i) when forecasting profits;

(ii) when allocating resources to product lines;

(iii) when measuring management's effectiveness; and

(iv) when evaluating new business proposals (Schoeffler, Buzzell \& Heany, 1974: 137-138).

Should it be found, however, that a negative or no relationship existed, management would have to seek alternative strategies in order to increase return on investment.

In this regard, two studies (Woo \& Cooper, 1982: 106-113; and Woo, 1984: 50-54) showed that under certain circumstances a small company can be successful.

\section{Empirical study}

With this in mind an empirical study was done on two market sectors, namely listed retail companies (Group A) and listed companies involved in the manufacturing and distribution of furniture (Group B). The period involved was 1975-1985. Listed companies were decided on due to the availability of their financial reports.

\section{Method of study}

With the aid of summarizing computer print-outs from the Bureau of Financial Analysis at the University of Pretoria the following data were obtained from the companies' annual reports: (i) Pre-tax profit; (ii) return on investment; (iii) turnover; and (iv) total shareholders equity.

The data were tabled per year and the following calculations were made:

(i) The market share was calculated by expressing each company's sales (turnover) per year as a percentage of the total sales for the complete market for the same year. Markets were established by grouping companies according to the largest part of their activities as described in 'The Stock Exchange Handbook' of August 1984. The assumption was made that the companies 
involved were big enough to qualify their groups as complete markets.

(ii) Market share was compared to rate of return in two different ways. Firstly, the correlation coefficient between the two variables for each company for 11 years was established. Secondly, the correlation between market share and return on investment was calculated per year for a group of companies (market).

(iii) In order to conduct a control study, the turnover and profit of the companies were compared in the same way as described above. All figures were changed to 1975 prices by means of the consumer price index in order to eliminate the effect of inflation. These values were then indexed with 1975 as basis year to be able to have them on a comparable basis.

(iv) A further control study was conducted to establish any relationship between rate of return and the economic cycle. This was done by comparing the rate of return index and the gross national product index for the period of the study.

During all the above comparisons a correlation coefficient of a $5 \%$ level of reliability was sought.

\section{Findings}

(i) Tables 1 and 2 show the correlation between return on investment and the market share for the individual companies for the period 1975 - 1985. In Table 1 only three of the 22 companies $(13,6 \%)$ showed a significant positive correlation on a $5 \%$ level of reliability between return on investment and market share. It subsequently appears that no overall relationship exists. The appearance of both positive and negative values tend to confirm this.

(ii) The figures stated in (i) are verified by the fact that only three out of 44 values $(6,8 \%)$ indicated a significant positive correlation on a $5 \%$ level of reliability when the rate of return and market share of each market segment is compared on a yearly basis (Table 3). The findings in (i) and (ii) indicated that return on investment is not sensitive for variation in the market share of the companies included in this study.

(iii) The period involved in this study was characterized by a fluctuating economic cycle (see Figure 1).
Table 1 Correlation (r) between return on investment and the market share of each company in Group A: 1975-1985

\begin{tabular}{|c|c|c|c|}
\hline Name & $\begin{array}{l}\text { Corre- } \\
\text { lation } \\
r\end{array}$ & $\begin{array}{c}\text { Period of } \\
\text { observation } \\
\text { (years) }\end{array}$ & $\begin{array}{l}\text { Required correlation } \\
\text { for a } 5 \% \text { level } \\
\text { of reliability }\end{array}$ \\
\hline 1. Foschini Ltd. & 0,87 & 11 & $0,602^{*}$ \\
\hline Hepworths Lid. & $-0,30$ & 6 & 0,811 \\
\hline John Orr Holdings Ltd. & $-0,28$ & 11 & 0,602 \\
\hline 2. Edgars Stores Ltd. & 0,37 & 11 & 0,602 \\
\hline Frasers Ltd. & 0,42 & 11 & 0,602 \\
\hline Garlick Ltd. & $-0,51$ & 11 & 0,602 \\
\hline Wooltru Ltd. & 0,08 & 11 & 0,602 \\
\hline Spitz Ltd. & 0,70 & 11 & $0,602^{\bullet}$ \\
\hline 3. Gallo Ltd. & $-0,09$ & 11 & 0,602 \\
\hline Clicks Stores Ltd. & $-0,52$ & 7 & 0,754 \\
\hline Gresham Industr. Ltd. & 0,14 & 11 & 0,602 \\
\hline Waltons Ltd. & 0,18 & 7 & 0,754 \\
\hline Metro Group Ltd. & $-0,62$ & 9 & 0,666 \\
\hline 4. Pepkor Ltd. & $-0,64$ & 11 & 0,602 \\
\hline Grand Bazaars Ltd. & 0,68 & 11 & $0,602^{*}$ \\
\hline Kirsh/Tradegro Ltd. & 0,46 & 11 & 0,602 \\
\hline O.K. Bazaars (1929) Ltd. & 0,59 & 11 & 0,602 \\
\hline Pick 'n Pay Stores Ltd. & $-0,59$ & 11 & 0,602 \\
\hline
\end{tabular}

- Significant positive correlation on a $5 \%$ level of reliability

Table 2 Correlation ( $r$ ) between return on investment and the market share of each company in Group A: 1975-1985

\begin{tabular}{|c|c|c|c|}
\hline Name & $\begin{array}{l}\text { Corre- } \\
\text { lation } \\
r\end{array}$ & $\begin{array}{c}\text { Period of } \\
\text { observation } \\
\text { (years) }\end{array}$ & $\begin{array}{l}\text { Required correlation } \\
\text { for a } 5 \% \text { level } \\
\text { of reliability }\end{array}$ \\
\hline Amrel Ltd. & $-0,76$ & 11 & 0,602 \\
\hline Beares Ltd. & $-0,37$ & 11 & 0,602 \\
\hline Bradlow Stores Ltd. & 0,13 & 11 & 0,602 \\
\hline Ellerine Holdings Ltd. & $-0,07$ & 10 & 0,632 \\
\hline Montays Ltd. & $-0,68$ & 7 & 0,754 \\
\hline Russell Holdings Ltd. & 0,53 & 8 & 0,707 \\
\hline Samstel Ltd. & $-0,35$ & 9 & 0,666 \\
\hline \multicolumn{4}{|l|}{ World Furnishers Group } \\
\hline Ltd. & $-0,21$ & 11 & 0,602 \\
\hline
\end{tabular}

Table 3 Relationship between rate of return and the market share for each market segment per year

\begin{tabular}{lrrrrrrrrrrr}
\hline & \multicolumn{10}{c}{ Year } \\
\cline { 2 - 12 } Group & 1975 & 1976 & 1977 & 1978 & 1979 & 1980 & 1981 & 1982 & 1983 & 1984 & 1985 \\
\hline A2 & 0,81 & 0,80 & 0,68 & 0,46 & 0,83 & 0,80 & 0,40 & 0,28 & 0,68 & 0,67 & 0,79 \\
A3 & 0,46 & 0,54 & $0,92^{2}$ & $0,97^{*}$ & $0,91^{*}$ & 0,70 & 0,07 & $-0,18$ & $-0,16$ & 0,41 & 0,25 \\
A4 & $-0,61$ & $-0,63$ & $-0,72$ & $-0,81$ & $-0,66$ & $-0,66$ & $-0,76^{*}$ & $-0,49$ & $-0,41$ & $-0,08$ & $-0,09$ \\
B1 & 0,02 & 0,76 & 0,61 & 0,61 & 0,70 & 0,55 & 0,78 & 0,62 & $-0,11$ & $-0,20$ & $-0,49$ \\
\hline
\end{tabular}

- Significant positive correlation on a $5 \%$ level of reliability 


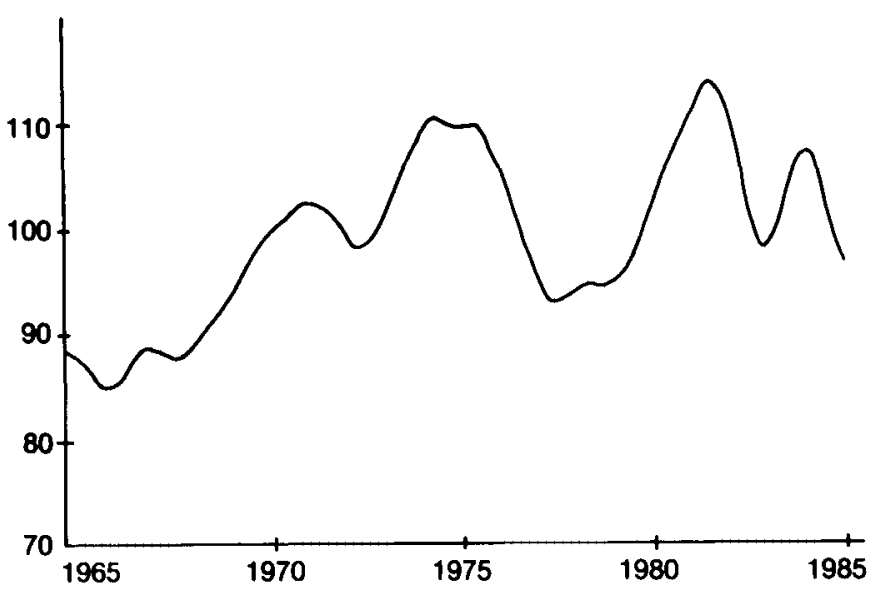

Figure 1 South African business cycle: 1966-1985. (Adapted from: University of Stellenbosch, 1985.)

Although no significant relationship on a $5 \%$ level of reliability could be obtained between return on investment and the economic cycle, a larger correlation was obtained than between return on investment and market share. The possibility subsequently exists that the economic cycle could have reduced the effect of market share on return on investment to such a level that it was not measurable.

(iv) Only six of the 23 companies (26\%) showed a significant relationship between profit and turnover. Although all the correlations obtained were not significant, it is interesting to note that $54 \%$ of the values indicated a positive correlation and $46 \%$ a negative correlation. The low appearance of significant relationships as well as the almost equal split between positive and negative values of correlation indicates that profit is not significantly sensitive to the turnover of the companies included in this study. The results of this control study further confirm the reliability of the findings discussed under (i) and (ii).

These findings must be viewed against the following background: Different companies' rates of return can not be compared accurately due to differences in the utilization of capital. It was found difficult to group companies in homogenic markets due to the diversified activities of South African companies.

\section{Suggestions for future research}

As a result of the study, the following suggestions for future research are applicable:

(i) A South African equivalent for the PIMS data bank should be established;

(ii) a similar study, based on this data bank should be executed, preferably during a more stable economic climate;

(iii) the possible influence of the economic cycle should be looked at in more depth;

(iv) the influence of possible third factors should also be investigated; (v) various combinations of factors should be investigated for a possible combined effect that might be significant;

(vi) due to the high degree of diversification of South African companies, the companies involved in the study should be further subdivided in departments in order to obtain even more homogenic markets;

(vii) as in the case of the PIMS data bank as many as possible participating companies should be obtained in order to get a more representative sample;

(viii) differences in the application of capital by the various companies should also be kept in mind, as it has a direct effect on return on investment; and

(ix) relationships other than linear relationships should be investigated.

\section{Conclusion}

This study is of great importance as can be seen from extensive research on this subject in the United States of America. The need for accurate findings in this field exists as it is important to establish whether the marketing objective of increasing market share is in line with the company objective of maximizing return on investment.

\section{References}

Baumol, W.J. 1959. Business behaviour, value and growth. New York: The Macmillan Company. 164p.

Bloom, P.N. \& Kotler, P. 1975. Strategies for high market-share companies. Harv. Bus. Rev., vol. 53, Nov./Dec., 63-72.

Buzzell, R.D., Gale, B.T. \& Sultan, R.G.M. 1975. Market share - a key to profitability. Harv. Bus. Rev., vol. 53, Jan./Feb., 97-106.

Buzzell, R.D. \& Wiersema, F.D. 1981. Successful share-building strategies. Harv. Bus. Rev., vol. 59, Jan./Feb., 135-144.

Catry, B. \& Chevalier, M. 1974. Market share strategy and the product life cycle. J. Market., vol. 38, October, 29-33.

Faul, M.A., Pistorius, C.W.I. \& Van Vuuren, L.M. 1981. Rekeningkunde: ' $n$ inleiding. Durban: Butterworths. 629p.

Garrison, R.H. 1985. Managerial Accounting: Concepts for planning, control, decision making. 4th Edition. Plano, Texas: Business Publications, Inc. 814p.

Hansen, H.L. 1958. Marketing - text, cases and readings. 4th Edition. Homewood: Irwin. 799p.

Hise, R.T. \& Strawser, R.H. 1972. The validity of market share as a marketing objective, some disconcerting evidence. S. J. Bus., August, 8-20.

Jacobson, R. \& Aaker, D.A. 1985. Is market share all that it's cracked up to be? J. Market., vol. 49, Fall edition, 11-22.

Koontz, H., O'Donnell, C. \& Weihrich, H. 1984. Management. 8th Edition. Tokyo: McGraw-Hill International Book Company. 682p.

Monroe, K.B. 1979. Pricing: Making profitable decisions. New York: McGraw-Hill Book Company. 286p.

Rädel, F.E. \& Reynders, H.J.J. (Reds.) 1980. Inleiding tot die Bedryfsekonomie. 4de Uitgawe. Pretoria: J.L. van Schaik Bpk. 632p. 
Reynders, H.J.J., Lambrechts, I.J. \& Scheurkogel, A.E. 1985. Finansiële Bestuur. 3de Uitgawe. Pretoria: J.L. van Schaik Bpk. 668p.

Schoeffler, S., Buzzell, R.D. \& Heaney, D.F. 1974. Impact of strategic planning on profit performance. Harv. Bus. Rev., vol. 52, March/April, 137-145.

Thompson, C.G. 1984. The Stock Exchange Handbook. Johannesburg: Flesch Financial Publications (Pty.) Ltd. August, 502p.
University of Stellenbosch. 1985. Trends: A statistical analysis of economic trends. Bureau for Economic Research, vol. 8, No. 3, September.

Wagner, H.M. 1984. Profit wonders, investment blunders. Harv. Bus. Rev., vol. 62, Sept./Oct., 121-135.

Woo, C.Y. 1984. Market-share leadership - not always so good. Harv. Bus. Rev., vol. 62, Jan/Feb., 50-54.

Woo, C.Y. \& Cooper, A.C. 1982. The surprising case for low market share. Harv. Bus. Rev., vol.60, Nov./Dec., 106-113. 